\title{
Impairment of Glucose-induced Insulin Secretion in Human Pancreatic Islets Transplanted to Diabetic Nude Mice
}

Leif Jansson, Décio L. Eizirik, Daniel G. Pipeleers, ${ }^{*}$ L. A. Håkan Borg, Claes Hellerström, and Arne Andersson Department of Medical Cell Biology, Uppsala University, S-751 23 Uppsala, Sweden; and *Department of Metabolism and Endocrinology, Vrije Universiteit Brussel and $\beta$-Cell Transplant, Brussels, Belgium

\begin{abstract}
Hyperglycemia-induced $\beta$-cell dysfunction may be an important component in the pathogenesis of non-insulin-dependent diabetes mellitus. However, most available data in this field were obtained from rodent islets. To investigate the relevance of this hypothesis for human $\beta$-cells in vivo, human pancreatic islets were transplanted under the renal capsule of nude mice. Experimental groups were chosen so that grafted islets were exposed to either hyper- or normoglycemia or combinations of these for 4 or 6 wk. Grafts of normoglycemic recipients responded with an increased insulin release to a glucose stimulus during perfusion, whereas grafts of hyperglycemic recipients failed to respond to glucose. The insulin content of the grafts in the latter groups was only $10 \%$ of those observed in controls. Recipients initially hyperglycemic ( $4 \mathrm{wk}$ ), followed by 2 wk of normoglycemia regained a normal graft insulin content, but a decreased insulin response to glucose remained. No ultrastructural signs of $\beta$-cell damage were observed, with the exception of increased glycogen deposits in animals hyperglycemic at the time of killing. It is concluded that prolonged exposure to a diabetic environment induces a long-term secretory defect in human $\beta$-cells, which is not dependent on the size of the islet insulin stores. (J. Clin. Invest. 1995. 96:721-726.) Key words: $\beta$-cells • insulin secretion • hyperglycemia $\bullet$ islets $\cdot$ transplantation
\end{abstract}

\section{Introduction}

Persistent hyperglycemia has been suggested to contribute to the impaired $\beta$-cell function observed in non-insulin-dependent diabetes mellitus and during the early stages of insulin-dependent diabetes mellitus (1-3). That this can occur also in experimental animals in vivo has been well documented both for rats (4-6) and some strains of mice (7). Whether such glucose effects are present in cultured islets is at present debated. Several reports suggest that so-called "glucose toxicity" can be observed in cultured rodent islets $(8-11)$, whereas we and others have been unable to observe such effects $(12-16)$. These discrepancies may be explained by the use of different culture

Address correspondence to Dr. Arne Andersson, Department of Medical Cell Biology, Biomedical Center, P.O. Box 571, S-751 23 Uppsala, Sweden. Phone: 18-174397; FAX: 18-556401.

Received for publication 6 February 1995 and accepted in revised form 26 April 1995.

J. Clin. Invest.

(C) The American Society for Clinical Investigation, Inc.

0021-9738/95/08/0721/06 \$2.00

Volume 96, August 1995, 721-726 conditions and, most likely, by genetic differences between the strains of animals used (see reference 7).

Studies in humans have demonstrated that intensive insulin therapy in early stages of insulin-dependent diabetes mellitus is able to improve $\beta$-cell function (17-19). In vitro studies on human islets have been difficult to perform since the availability of well defined human islets is scarce. However, it was demonstrated recently that isolated human islets exposed to high ambient glucose concentrations for $7 \mathrm{~d}$ in culture showed an impaired $\beta$-cell function (20). The aim of the present study was to evaluate if prolonged periods of hyperglycemia in vivo affect insulin release from transplanted human islets. For this purpose, islets were exposed to different periods of normoglycemia and hyperglycemia after implantation into the subcapsular space of the kidney of athymic nude mice. The graft-bearing kidney was then perfused, and glucose-stimulated insulin release from the grafted human islets was evaluated. In some experiments the insulin content and the ultrastructural appearance of the grafts were also assessed.

\section{Methods}

Islet isolation and culture. Nine human pancreata were excised from adult heart-beating organ donors and transported to the Central Unit of the $\beta$-Cell Transplant (Medical Campus, Vrije Universiteit Brussel). The islets were then isolated as described previously (20). The mean age of the donors was $35 \pm 5 \mathrm{yr}$ (mean \pm SEM, range 14-64 yr). Aliquots of the islet-enriched fraction obtained after the isolation procedure were examined with electron microscopy, which indicated the presence of $4.6 \pm 1.1 \%$ dead cells and $1.6 \pm 0.6 \%$ acinar cells in the preparations. Light microscopical examination of immunocytochemically stained islets (21) showed the presence of $56 \pm 3 \%$ insulin positive cells and $6.9 \pm 0.7 \%$ glucagon positive cells. The islet insulin content was $1.48 \pm 0.28 \mathrm{ng}$ insulin/ng DNA.

After isolation the human islets were cultured in Brussels in Ham's F10 (Flow Laboratories, Irvine, Strathclyde, United Kingdom) containing $6.1 \mathrm{mmol} /$ liter $\mathrm{D}$-glucose, and supplemented with $0.5 \%$ bovine serum albumin, $0.08 \mathrm{mg} / \mathrm{ml}$ penicillin, and $0.1 \mathrm{mg} / \mathrm{ml}$ streptomycin. The culture period in Brussels varied between 2 and $6 \mathrm{~d}$ (mean \pm SEM; $4.0 \pm 0.8 \mathrm{~d}$ ). The islets were subsequently sent by air to Uppsala, Sweden (transport time 4-8 h) in the culture medium referred to above, but further supplemented with $2 \%$ newborn calf serum and $10 \mathrm{mmol} / \mathrm{liter}$ Hepes. There they were cultured free-floating in groups of 100-150 islets/culture dish in RPMI 1640 (Flow) containing $5.6 \mathrm{mmol} /$ liter Dglucose, $10 \%$ fetal calf serum, $100 \mathrm{U} / \mathrm{ml}$ benzylpenicillin, and $0.1 \mathrm{mg} /$ $\mathrm{ml}$ streptomycin for 6-8 d with medium changes every $2 \mathrm{~d}(20)$.

Islet transplantation. Athymic male nude mice (C57BL/6 [nu/nu]; Bomholtgaard, Ry, Denmark) weighing 20-25 grams were used as recipients in all experiments. Some of the animals were made diabetic by an intravenous injection of alloxan $(80 \mathrm{mg} / \mathrm{kg}$ body wt; Sigma Chemical Co., St. Louis, MO) 3-5 d before transplantation. The animals were anesthetized with avertin (see reference 22) and the left kidney was visualized with a flank incision. An incision was made in the renal capsule, and $\sim 3 \mu \mathrm{l}(\approx 300)$ of human islets was implanted by means of a braking pipette. The transplantation of this number of human islets 
is usually not sufficient to cure alloxan-diabetic nude mice (23), although the occasional animal normalizes its hyperglycemia. When implanting $\sim 400$ human islets into diabetic nude mice, normoglycemia was regularly obtained (24). The wound was closed by sutures, and the animals were then observed until fully recovered from anesthesia. Some of the animals also received an intrasplenic implant consisting of $\approx 200$ islets from C57BL/6 $(o b / o b)$ mice, that has been shown previously to normalize hyperglycemia of syngeneic alloxan-diabetic recipients (25). These islets had been isolated with a collagenase digestion method and cultured for 1-2 $\mathrm{d}$ in the medium given above for culture of human islets in Uppsala, but containing $11 \mathrm{mmol} /$ liter glucose (26). The mouse islets were implanted in avertin-anesthetized mice into the splenic pulp via a microinfusion set. The size of this graft was chosen so that the combined actions of 300 human islets and 200 mouse islets were sufficient to normalize the blood glucose of alloxan-diabetic nude mice.

Experimental groups were designated as follows based on the assumptions that 300 human islets transplanted alone are insufficient to alone maintain normoglycemia in alloxan-diabetic recipients, whereas $200 \mathrm{ob} / \mathrm{ob}$ islets with or without the simultaneous presence of 300 human islets have this capacity: $(a)$ normoglycemic recipients transplanted with human islets $4 \mathrm{wk}$ before killing $(4 \mathrm{~N}) ;(b)$ alloxan-diabetic recipients transplanted with human islets $4 \mathrm{wk}$ before killing $(4 \mathrm{H}) ;(c)$ alloxan-diabetic recipients transplanted with human islets. $4 \mathrm{wk}$ later, i.e., after $4 \mathrm{wk}$ of hyperglycemia, an intrasplenic $o b / o b$ mouse islet transplant was given. This normalized the blood glucose concentration and the animals then remained normoglycemic for 2 wk before being killed $(4 \mathrm{H}+2 \mathrm{~N})$; and $(d)$ alloxan-diabetic recipients cured by an intrasplenic graft consisting of 200 islets isolated from obese C57BL/ 6 mice. When these mice had been normoglycemic for 2 wk they were given the subcapsular human islet graft $(\approx 300$ islets $) .2 \mathrm{wk}$ later splenectomy was performed and the mice then became hyperglycemic for $4 \mathrm{wk}(2 \mathrm{~N}+4 \mathrm{H})$.

Blood samples for determination of blood glucose concentrations with glucose reagent strips (ExacTech ${ }^{\circledast}$; Baxter Travenol Inc., Deerfield, IL) were collected from the cut tip of the tail. Determinations were made before transplantation, when a splenectomy or intrasplenic implantation was performed, or immediately before perfusion. No samples were collected from mice which were not treated with alloxan.

Perfusion of graft-bearing kidneys. This technique has been described in detail elsewhere (27). Briefly, animals were anesthetized with avertin and the graft-bearing kidney removed together with part of the aorta and inferior vena cava. The ureter and renal vein were cut, whereas the aorta was cannulated and perfused with a continuously gassed $\left(\mathrm{O}_{2} / \mathrm{CO}_{2}=95: 5\right)$ Krebs-Ringer bicarbonate buffer (28) supplemented with $10 \mathrm{mmol} / \mathrm{liter}$ Hepes, $2 \%$ (wt/vol) each of dextran (Dextran T70; Pharmacia Fine Chemicals, Uppsala, Sweden) and bovine serum albumin (Fraction V; Miles Laboratories, Slough, United Kingdom) and 2.8 or $16.7 \mathrm{mmol} /$ liter D-glucose. The medium was administered at a rate of $1 \mathrm{ml} / \mathrm{min}$ without recycling for $75 \mathrm{~min}$ with a perfusion pressure of $40-50 \mathrm{mmHg}$.

Perfusion experiments started with a 30 -min period using a medium containing $2.8 \mathrm{mmol} /$ liter glucose, followed by $30 \mathrm{~min}$ with $16.7 \mathrm{mmol} /$ liter glucose and finally $15 \mathrm{~min}$ with $2.8 \mathrm{mmol} /$ liter glucose. A $1.0-\mathrm{ml}$ sample of the effluent medium was collected 15 and $29 \mathrm{~min}$ after starting the initial equilibration period, and then every fifth minute. However, during the first $10 \mathrm{~min}$ of perfusion with the high glucose concentration, samples were taken after $1-5,7$, and $10 \mathrm{~min}$. The insulin concentrations of these samples were measured by radioimmunoassay (29). After perfusion the human islet graft was carefully dissected free from surrounding renal tissues (27) and analyzed for its insulin content (see below).

The total insulin response to glucose during the 30-min stimulation period with $16.7 \mathrm{mmol} /$ liter glucose was calculated by planimetry of the area of each individual perfusion curve (7). A value of $0.25 \mathrm{ng}$ insulin/min was designated as zero, since this represented the lower limit of sensitivity for the insulin assay used.

Insulin content of the islet grafts. The grafts were homogenized in
Table I. Blood Glucose Concentrations and Corresponding Graft Insulin Content of Normoglycemic or Hyperglycemic Nude Mice Transplanted (tx) with Islets under the Renal Capsule

\begin{tabular}{ccccc}
\hline $\begin{array}{c}\text { Time after tx (wk) } \\
\text { No. of animals }\end{array}$ & $\begin{array}{c}4 \mathrm{~N} \\
13\end{array}$ & $\begin{array}{c}4 \mathrm{H} \\
10\end{array}$ & $\begin{array}{c}4 \mathrm{H}+2 \mathrm{~N} \\
9\end{array}$ & $\begin{array}{c}2 \mathrm{~N}+4 \mathrm{H} \\
4\end{array}$ \\
\hline $\begin{array}{c}\text { Blood glucose } \\
\quad(\mathrm{mmol} / \mathrm{liter})\end{array}$ & & & & \\
Before tx & $\mathrm{ND}$ & $23.7 \pm 0.8$ & $>25.0$ & $24.6 \pm 0.6$ \\
4 wk after tx & ND & $21.2 \pm 3.8$ & $22.7 \pm 2.3$ & $4.0 \pm 0.3^{*}$ \\
6 wk after tx & - & - & $3.4 \pm 0.4^{*}$ & $18.6 \pm 3.2$ \\
$\begin{array}{c}\text { Graft insulin } \\
\text { content }(\mu \mathrm{g})\end{array}$ & $12.9 \pm 4.5$ & $1.4 \pm 0.3^{\ddagger}$ & $11.4 \pm 4.4$ & $2.5 \pm 1.0^{\ddagger}$ \\
& & & &
\end{tabular}

Values are means \pm SEM, and statistical significances were calculated with Student's unpaired $t$ test. $N D$, not determined. $* P<0.001$ when compared with the value before $\mathrm{tx}$ in the same group of animals. ${ }^{\ddagger} P$ $<0.001$ when compared with normoglycemic mice.

redistilled water as described previously (7), and then sonicated to disrupt any remaining intact cells. Samples from the homogenate were extracted overnight at $4^{\circ} \mathrm{C}$ in acid ethanol $(0.18 \mathrm{M} \mathrm{HCl}$ in $95 \%$ [vol/ vol] ethanol) and analyzed for insulin content with radioimmunoassay.

Morphological examination of islet grafts. Separate animals from groups $4 \mathrm{~N}(n=2), 4 \mathrm{H}(n=2)$, and $4 \mathrm{H}+2 \mathrm{~N}(n=3)$ were used in these experiments. The animals were killed by cervical dislocation 4 or $6 \mathrm{wk}$ after islet transplantation. The islet grafts, together with $\sim 1-$ $2 \mathrm{~mm}$ of adjacent renal parenchyma, were rapidly dissected out and immediately fixed in chilled $2.5 \%$ ( $\mathrm{vol} / \mathrm{vol}$ ) glutaraldehyde in a phosphate buffer ( $36 \mathrm{mmol} / \mathrm{liter} \mathrm{NaH}_{2} \mathrm{PO}_{4}$ and $14 \mathrm{mmol} /$ liter $\mathrm{KH}_{2} \mathrm{PO}_{4} ; \mathrm{pH}$ 7.2). After postfixation in $1 \%(\mathrm{wt} / \mathrm{vol})$ osmium tetroxide, the tissue was dehydrated in graded ethanol and embedded in Epon 812 (Shell Chemical Corp., San Francisco, CA). The islet grafts were identified in semithin sections stained with $1 \%(\mathrm{wt} / \mathrm{vol})$ toluidine blue in 25 $\mathrm{mmol} /$ liter disodium tetraborate. Ultrathin sections were then prepared and electron microscopy was performed as described in detail elsewhere (30).

Statistical calculations. All values are given as means \pm SEM. Probabilities of chance differences have been calculated with Student's twotailed unpaired $t$ test or ANOVA.

\section{Results}

The nude mice tolerated the surgical procedures well, and mortality was low $(<5 \%)$ and mainly due to infections manifested immediately after the operations. The alloxan-treated animals used in groups $4 \mathrm{H}, 4 \mathrm{H}+2 \mathrm{~N}$, and $2 \mathrm{~N}+4 \mathrm{H}$ all had blood glucose concentrations $>15 \mathrm{mmol} /$ liter at $4 \mathrm{wk}$ after transplantation of human islets only (Table I). Implantation of the additional 200 mouse islets into the spleen (group $4 \mathrm{H}+2 \mathrm{~N}$ ) or splenectomy (group $2 \mathrm{~N}+4 \mathrm{H}$ ) produced the expected normalization of blood glucose and return of diabetes, respectively (Table $\mathrm{I}$ ).

The electron microscopical appearance of $\beta$-cells in human islets transplanted to animals from group $4 \mathrm{~N}$ was normal, and no signs of rejection were discerned. However, the $\beta$-cells had few secretory granules (Fig. $1 A$ ). The $\beta$-cells of the animals hyperglycemic at the time of killing (group $4 \mathrm{H}$ ) also had very few secretory granules and a well-developed secretory apparatus. A special feature of these $\beta$-cells was the high content of glycogen particles (Fig. $1 \mathrm{~B}$ ). When the blood glucose concentration of the alloxan-diabetic mice had been normalized by a second curative intra-splenic mouse islet graft (group $4 \mathrm{H}$ 

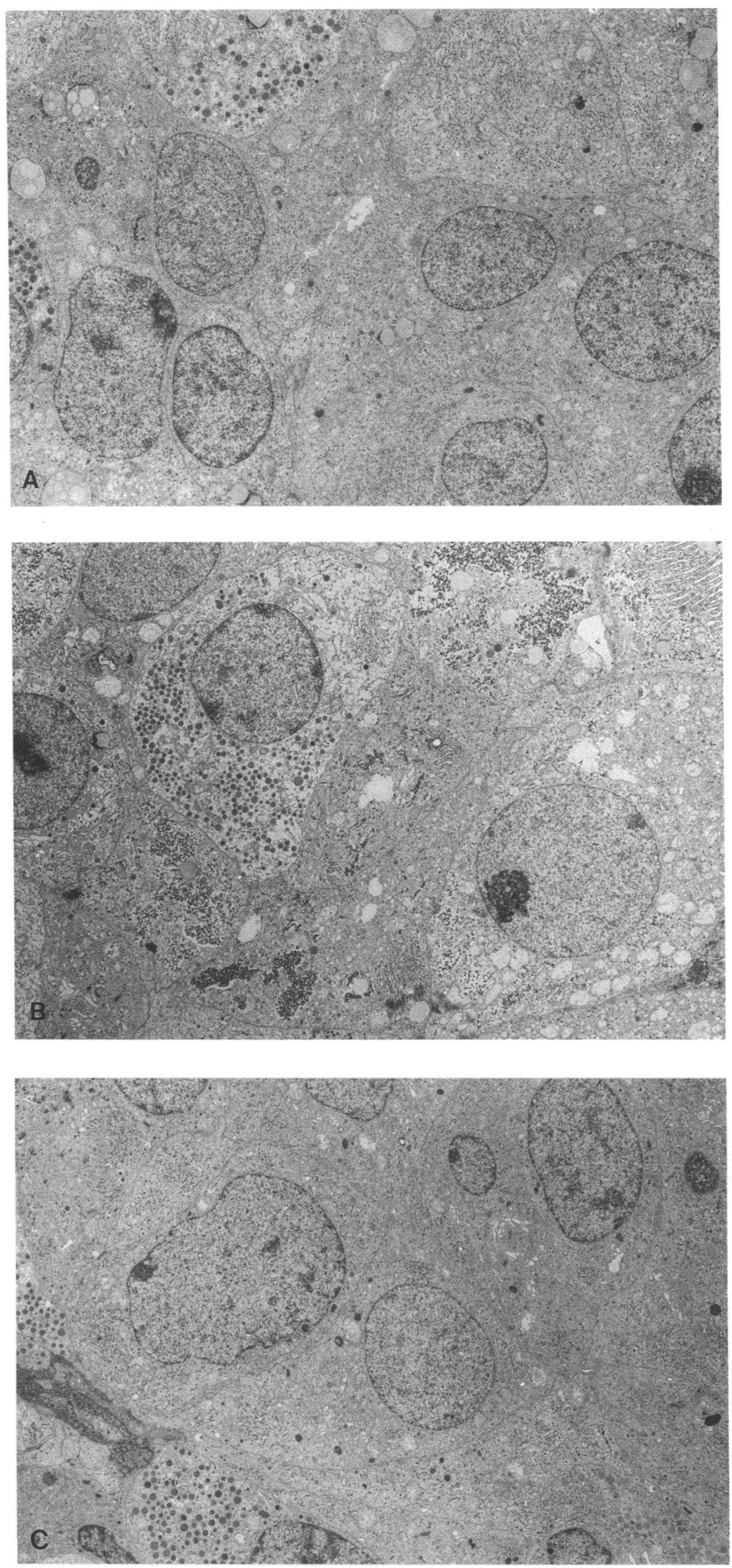

Figure 1. Electron micrographs of human islets transplanted under the renal capsule of athymic nude mice normoglycemic for $4 \mathrm{wk}(A)$, hyperglycemic for $4 \mathrm{wk}(B)$, or hyperglycemic for $4 \mathrm{wk}$ followed by normoglycemia for 2 wk $(C) . \times 6,750$.

Hyperglycemia and Human Islet Function 


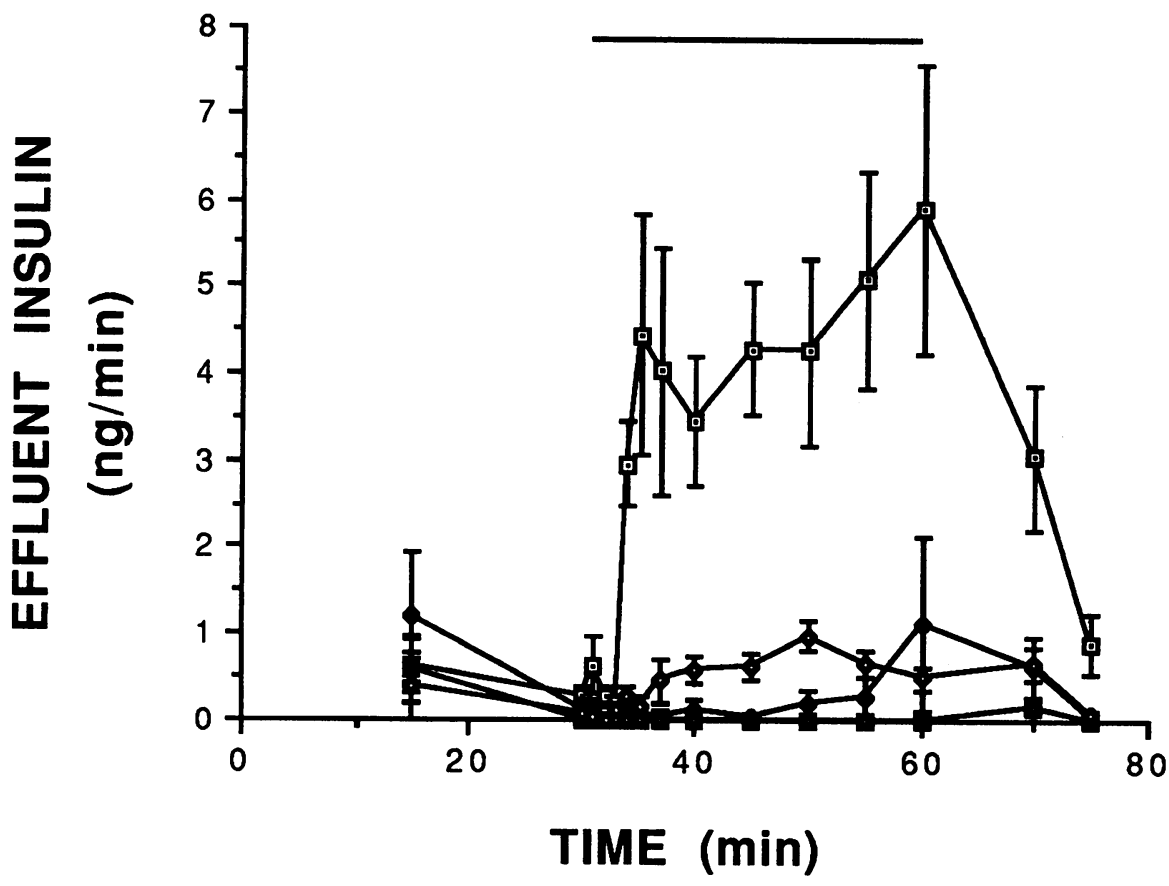

Figure 2. Insulin concentration in the effluent medium collected from human islet graftbearing kidneys of nude mice 4 or $6 \mathrm{wk}$ after transplantation. Kidneys were perfused with a medium containing 2.8 or $16.7 \mathrm{mmol} /$ liter (bar at top of figure) D-glucose. The curves represent data from recipients normoglycemic for 4 wk (group 4N; open squares, $n$ $=7$ ), hyperglycemic for $4 \mathrm{wk}$ (group $4 \mathrm{H}$; filled squares, $n=5$ ), hyperglycemic for 4 wk followed by normoglycemia for $2 \mathrm{wk}$ (group $4 \mathrm{H}+2 \mathrm{~N}$; open circles, $n=5$ ), and normoglycemic for 2 wk followed by hyperglycemia for $4 \mathrm{wk}$ (group $2 \mathrm{~N}+4 \mathrm{H}$, filled circles, $n=4)$.
$+2 \mathrm{~N}$ ), the $\beta$-cells of the subcapsular human islet graft had an appearance very similar to that seen in the control animals (group $4 \mathrm{~N}$ ) with disappearance of the glycogen deposits.

The graft insulin content did not differ significantly between normoglycemic control animals (group 4N) and animals in which reversal to normoglycemia had been obtained with the intrasplenic mouse islet graft (group $4 \mathrm{H}+2 \mathrm{~N}$; Table I). However, the animals hyperglycemic at the time of examination (groups $4 \mathrm{H}$ and $2 \mathrm{~N}+4 \mathrm{H}$ ) demonstrated a marked reduction in graft insulin content (Table I).

Normoglycemic recipients (group $4 \mathrm{~N}$ ) exhibited a biphasic insulin response to glucose in the perfusion experiments (Fig. 2 ). Diabetes at the time of perfusion led to an almost totally absent glucose-induced insulin release, irrespective of whether hyperglycemia had been maintained for 4 wk (group $4 \mathrm{H}$, Fig. 2 ) or whether the animals had been initially normoglycemic for 2 wk followed by 4 wk of hyperglycemia (group $2 \mathrm{~N}+4 \mathrm{H}$, Fig. 2). In animals hyperglycemic for 4 wk followed by $2 \mathrm{wk}$ of normoglycemia (group $4 \mathrm{H}+2 \mathrm{~N}$ ) a markedly diminished glucose-induced insulin release was seen when compared with animals normoglycemic throughout the study (Fig. 2). When the total insulin output during the 30 -min glucose stimulation was calculated, all three experimental groups using alloxandiabetic mice (groups $4 \mathrm{H}, 4 \mathrm{H}+2 \mathrm{~N}$, and $2 \mathrm{~N}+4 \mathrm{H}$ ) demonstrated a markedly diminished insulin output compared with normoglycemic control animals (Fig. 3). However, animals in group $4 \mathrm{H}+2 \mathrm{~N}$ had a higher insulin response when compared with groups $4 \mathrm{H}$ and $2 \mathrm{~N}+4 \mathrm{H}$, i.e., animals hyperglycemic at the time of perfusion (Fig. 3 ).

\section{Discussion}

The human islets studied $4 \mathrm{wk}$ after implantation into normogly cemic recipients demonstrated a biphasic glucose-stimulated insulin release, which promptly returned to prestimulatory levels when the glucose stimulus was withdrawn, thereby indicating a well preserved viability of the preparations. Thus, the presently used technique offers a unique opportunity to evaluate the function of human pancreatic islets exposed to different conditions in vivo. This is of particular relevance, considering that the isolation procedure of islets from the compact human pancreas is likely to cause some damage to the $\beta$-cells (see reference 31 ). The islets used in the present study have been well characterized, both morphologically and functionally, before transplantation. Furthermore, the long time periods in culture $(\approx 1 \mathrm{wk})$ and in vivo $(4$ or $6 \mathrm{wk})$ would have allowed the disappearance of any acute damage due to the isolation procedure. This was confirmed by the normal electron microscopical appearance of the grafts.

The present finding that human islet grafts exposed to hyperglycemia in vivo (groups $4 \mathrm{H}$ and $2 \mathrm{~N}+4 \mathrm{H}$ ) have a total lack of glucose-induced insulin release agrees with previous findings in human islets cultured in the presence of high glucose concentrations $(20,32)$. However, it should be noted that one recent report suggests that culture in high glucose concentrations is advantageous for the function of human islets (33). Whether this reflects differences in the isolation procedure (see above) or culture conditions is presently unknown. These discrepancies in in vitro studies further emphasize the need for in vivo studies to elucidate the effects of hyperglycemia on human islets.

Since the human islet grafts themselves were of insufficient size to cure the animals in this study, the absent insulin response in recipients hyperglycemic at the time of perfusion most certainly reflects a severely diminished insulin store of the $\beta$-cells. This is in line with the observed decreased insulin content and the markedly degranulated ultrastructural appearance. The absence of obvious ultrastructural signs of $\beta$-cell damage speaks against lasting injuries induced by glucose. Any interference of hyperglycemia with the engraftment process is unlikely to contribute to the present findings, since an initial 2-wk period of normoglycemia (group $2 \mathrm{~N}+4 \mathrm{H}$ ) did not improve the insulin release in response to glucose. It cannot be excluded, however, 


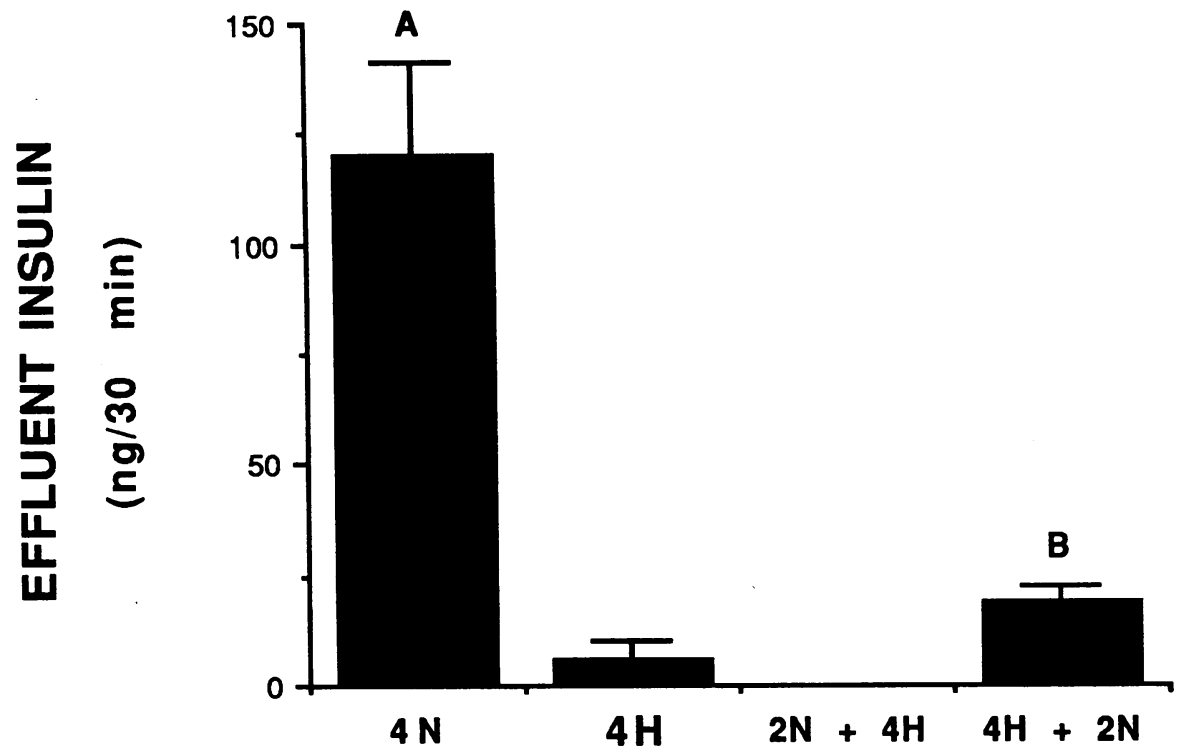

Figure 3. Total insulin secretion during $30 \mathrm{~min}$ from transplanted human islets in response to stimulation with $16.7 \mathrm{mmol} /$ liter D-glucose during perfusion of islet graft-bearing kidneys. The bars represent means \pm SEM for the same groups as given in the legend to Fig. 2. $A$ denotes $P<0.001$ when compared with groups $4 \mathrm{H}, 2 \mathrm{~N}+4 \mathrm{H}$, and $4 \mathrm{H}+2 \mathrm{~N}$ and $B$ denotes $P<0.01$ when compared with groups $4 \mathrm{H}$ and $2 \mathrm{~N}+4 \mathrm{H}$ as calculated with ANOVA. that hyperglycemia per se, especially when imposed upon a reduced mass of $\beta$-cells, may impair $\beta$-cell function (for reviews see references 2 and 3 ). If so, an initial period of hyperglycemia followed by normoglycemia would still be associated with an impaired function of transplanted human islets. This was indeed the case in this study. The amount of insulin secreted from the cured hyperglycemic animals (group $4 \mathrm{H}+2 \mathrm{~N}$ ) was higher than in hyperglycemic recipients but much reduced when compared with the controls. Thus, this is the first demonstration that prolonged hyperglycemia in vivo induces a defective insulin release in response to high glucose in human islets.

It is obvious, however, that this secretion defect cannot simply be explained by deficient insulin stores, since the insulin content of grafts from animals in group $4 \mathrm{H}+2 \mathrm{~N}$ was similar to that of permanently normoglycemic recipients. Of particular interest was the present finding that there was a marked increase in glycogen deposits, as seen in the electron microscopical slides after 4 wk of hyperglycemia. It is well known that high glucose concentrations can induce glycogen accumulation in the pancreatic islets both in vivo (34) and in vitro (35). It has also been suggested that glycogen may partake in hyperglycemia-induced islet dysfunction by interfering with glycolysis $(36,37)$. However, the disappearance of glycogen after reinstallment of normoglycemia, in combination with the persistence of islet functional impairment, argues against this notion.

The finding that a distinctly deficient insulin secretory response to glucose was established after 4 wk of hyperglycemia, despite subsequent normoglycemia for $2 \mathrm{wk}$, or in a few animals even for $4 \mathrm{wk}$ (our unpublished observation) is intriguing. This suggests that the insulin secretion defect induced by diabetes in the recipients may become of long duration or even permanent. The exact time period needed to induce reversible and/or irreversible hyperglycemia-induced $\beta$-cell impairment and the mechanisms involved in this process therefore require further studies.

\section{Acknowledgments}

The skilled technical assistance of B. Bodin, M. Engkvist, and A. Nordin is acknowledged. This study made use of human islets prepared by the Central Unit of the $\beta$-Cell Transplant.
This study was supported by a concerted action in Medical and Health Research of the European Community. The study was also supported by grants from the Swedish Medical Research Council (12X9237, connected to the $\beta$-Cell Transplant, European Concerted Action for the Treatment of Diabetes; 12X-109; 12X-9886; 12X-6538; 12P9287; and 19P-8982), the Juvenile Diabetes Foundation International, the Swedish Diabetes Association, the Novo-Nordisk Insulin Fund, the Family Ernfors Fund, BIOMED concerted action, the Vlaamse Gemeenschap (92/97-1807), and the Belgian Fonds voor Geneeskundig Wetenschappelijk Onderzoek (3.0057.94).

\section{References}

1. Unger, R. H., and S. Grundy. 1985. Hyperglycemia as an inducer as well as a consequence of impaired islet cell function and insulin resistance: implications for the management of diabetes. Diabetologia. 28:119-121.

2. Weir, G. C., J. L. Leahy, and S. Bonner-Weir. 1986. Experimental reduction of B-cell mass: implications for the pathogenesis of diabetes. Diabetes Metab. Rev. 2:125-161.

3. Rossetti, L., A. Giaccari, and T. A. DeFronzo. 1990. Glucose toxicity. Diabetes Care. 13:610-630.

4. Bonner-Weir, S., D. F. Trent, and G. C. Weir. 1983. Partial pancreatectomy in the rat and subsequent defect in glucose-induced insulin release. J. Clin. Invest. 71:1544-1554.

5. Leahy, J. L., and G. C. Weir. 1988. Evolution of abnormal insulin secretory responses during 48-h in vivo hyperglycemia. Diabetes. 37:217-222.

6. Portha, B., O. Blondel, P. Serradas, R. C. McEvoy, M.-H. Giroix, M. Kergoat, and D. Bailbe. 1989. The rat models of non-insulin dependent diabetes induced by neonatal streptozotocin. Diabete \& Metab. 15:61-75.

7. Korsgren, O., L. Jansson, S. Sandler, and A. Andersson. 1990. Hyperglycemia-induced B-cell toxicity. The fate of pancreatic islets transplanted into diabetic mice is dependent on their genetic background. J. Clin. Invest. 86:2161-2168.

8. Hoening, M., L. C. MacGregor, and F. M. Matschinsky. 1986. In vitro exhaustion of pancreatic $\beta$-cells. Am. J. Physiol. 250:E502-E511.

9. Bolaffi, J. L., A. Heldt, L. D. Lewis, and G. M. Grodsky. 1986. The third phase of in vitro insulin secretion. Evidence for glucose insensitivity. Diabetes. 35:370-373.

10. Purrelo, F., M. Vetri, C. Gatta, D. Gullo, and R. Vigneri. 1989. Effects of high glucose on insulin secretion by isolated rat islets and purified $\beta$-cells and possible role of glycosylation. Diabetes. 38:1417-1422.

11. Kaiser, N., A. P. Corcos, I. Sarel, and E. Cerasi. 1991. Monolayer culture of adult rat pancreatic islets on extracellular matrix: modulation of B-cell function by chronic exposure to high glucose. Endocrinology. 129:2067-2076.

12. Andersson, A., E. Borglund, and S. Brolin. 1974. Effects of glucose on the content of ATP and glycogen and the rate of glucose phosphorylation of isolated pancreatic islets maintained in tissue culture. Biochem. Biophys. Res. Commun. 56:1045-1051.

13. Bone, A. J., I. Swenne, and C. Hellerström. 1981. Effects of high glucose concentrations on the insulin biosynthesis of rat pancreatic islets maintained for extended periods in tissue culture. Diabete \& Metab. 7:259-263. 
14. Malaisse-Lagae, F., A. Sener, and W. J. Malaisse. 1986. Can desensitization of the $\beta$-cell to glucose be simulated in cultured pancreatic islets? Acto Diabetol. Lat. 24:17-25.

15. Eizirik, D. L., E. Strandell, and S. Sandler. 1988. Culture of mouse pancreatic islets in different glucose concentrations modifies B cell sensitivity to streptozotocin. Diabetologia. 31:168-174.

16. Svensson, C., and C. Hellerström. 1991. Long-term effects of a high glucose concentration in vitro on the oxidative metabolism and insulin production of isolated rat pancreatic islets. Metab. Clin. Exp. 40:513-518.

17. Mirouze, J., J. L. Selam, T. C. Pham, and A. Orsetti. 1978. Sustained insulin-induced remission of juvenile diabetes by means of an external artificial pancreas. Diabetologia. 14:223-227.

18. Madsbad, S., T. Krarup, O. K. Faber, C. Binder, and L. Regeur. 1982 The transient effect of strict glycaemic control on B-cell function in newly diagnosed type 1 (insulin-dependent) diabetic patients. Diabetologia. 22:16-20.

19. Shah, S., J. I. Malone, and N. E. Simpson. 1989. A randomized trial of intensive insulin therapy in newly diagnosed insulin-dependent diabetes mellitus. N. Engl. J. Med. 320:550-554.

20. Eizirik, D. L., G. S. Korbutt, and C. Hellerström. 1992. Prolonged exposure of human pancreatic islets to high glucose concentrations in vitro impairs the $\beta$ cell function. J. Clin. Invest. 90:1263-1268.

21. Pipeleers, D. G., P. A. In't Veld, M. Van de Winkel, E. Maes, F. C Schuit, and W. Gepts. 1985. A new in vitro model for the study of pancreatic A and B cells. Endocrinology. 117:806-816.

22. Korsgren, O., L. Jansson, D. L. Eizirik, and A. Andersson. 1991. Functional and morphological differentiation of fetal porcine islet-like cell clusters after transplantation into nude mice. Diabetologia. 34:379-386.

23. Westermark, P., D. L. Eizirik, D. G. Pipeleers, C. Hellerström, and A Andersson.1995. Rapid deposition of amyloid in human islets transplanted into nude mice. Diabetologia. 38:542-549.

24. Eizirik, D. L., D. G. Pipeleers, Z. Ling, N. Welsh, C. Hellerström, and A. Andersson. 1994. Major species differences between humans and rodents in the susceptibility to pancreatic $\beta$-cell injury. Proc. Natl. Acad. Sci. USA. 91:92539256.

25. Andersson, A., U. Eriksson, B. Petersson, L. Reibring, and I. Swenne. 1981. Failure of successful intrasplenic transplantation of islets from lean mice to cure obese-hyperglycaemic mice, despite islet growth. Diabetologia. 20:237241

26. Andersson, A. 1978. Isolated mouse pancreatic islets in culture: effects of serum and different culture media on the insulin production of the islets Diabetologia. 14:397-404.

27. Korsgren, O., L. Jansson, and A. Andersson. 1989. Effects of hyperglycemia on the function of isolated mouse pancreatic islets transplanted under the kidney capsule. Diabetes. 38:510-515.

28. Krebs, H. A., and K. Henseleit. 1932. Untersuchungen über die Harnstoffbildung im Tierkörper. Hoppe-Seyler's Z. Physiol. Chem. 210:33-66.

29. Heding, L. G. 1972. Determination of total serum insulin (IRI) in insulintreated diabetic patients. Diabetologia. 8:260-266.

30. Schnell, A. H., and L. A. H. Borg. 1988. Lysosomes and pancreatic islet function. A quantitative estimation of crinophagy in the mouse pancreatic $\beta$-cell. Cell Tissue Res. 252:9-15.

31. Ricordi, C., P. E. Lacy, E. H. Finke, B. J. Olack, and D. W. Scharp. 1988. Automated method for isolation of human pancreatic islets. Diabetes. 37:413 420.

32. Davalli, A. M., C. Ricordi, C. Socci, S. Braghi, F. Bertuzzi, B. Fattor, V. DiCarlo, A. E. Pontiroli, and G. Pozza. 1991. Abnormal sensitivity to glucose of human islets cultured in a high glucose medium: partial reversibility after an additional culture in a normal glucose medium. J. Clin. Endocrinol. \& Metab. 72:202-208.

33. Conget, I., Y. Sarri, A. Novials, R. Casamitjana, M. Vives, and R. Gomis. 1994. Functional properties of isolated human pancreatic islets: beneficial effects of culture and exposure to high glucose concentrations. Diabete Metab. 20:99107.

34. Toreson, W. E. 1951. Glycogen infiltration (so called hydropic degeneration) in the pancreas in human and experimental diabetes mellitus. Am. J. Pathol. 27:327-347.

35. Andersson, A., J. Westman, and C. Hellerström. 1974. Effects of glucose on the ultra-structure and insulin biosynthesis of isolated mouse pancreatic islets maintained in tissue culture. Diabetologia. 10:743-753.

36. Malaisse, W. J. 1993. Alteration of pancreatic B-cell D-glucose metabolism in type 2 diabetes: the $G$ quintet. Endocrinologia. 40:309-312.

37. Malaisse, W. J., C. Maggetto, V. Leclercq-Meyer, and A. Sener. 1993. Interference of glycogenolysis with glycolysis in pancreatic islets from glucoseinfused rats. J. Clin. Invest. 91:432-436. 